hypothesis to explain the anti-ketogenic action of carbohydrates. A session was also devoted to the consideration of lecithin degradation. Dr. M. Kahane (France) described his investigations into the presence of water-soluble choline esters in the blood and tissues, and Prof. J. Roche (France) gave an account of enzymological studies on the hydrolysis of phosphoryl choline and phosphoryl colamine by phosphatases. The structure and hydrolysis of egg lecithin were discussed by Prof. P. Fleury (France).

The nutritional importance of essential unsaturated fatty acids was discussed after a survey of work in this field had been given by Prof. K. Bernhard and Prof. R. H. Barnes. Miss E. Le Breton described experiments on fatty acid dehydrogenases. She described the relationship of certain vitamins and phosphorylation to the activity of these desaturases. Their possible significance in the problem of essential fatty acids was discussed.

In the concluding session, Dr. C. Paquot (France) described his work on the autoxidation of fats, and presented theoretical considerations, both on this question and on the subject of anti-oxidants. Prof. A. Chevallier (France) described apparent relationships between the oxidation and ultra-violet absorption of glycerides, and Prof. P. Dubouloz (France) spoke of his researches on anti-oxidants in relation to vitamin A. He discussed the mechanism of antioxidant action and described preliminary experiments on the physiological properties of peroxidized lipids. Prof. R. H. Barnes gave a survey of recent work carried out in the United States on anti-oxidants, and the development of oxidative rancidity in fats. He emphasized the possible importance of rancidity in biological processes.

The official business of the symposium was completed in eight days and was carried through in a most cordial atmosphere. The full proceedings, including summaries of the various discussions, will be published in due course in the Archives des Sciences Physiologiques.

\section{METABOLIC ASPECTS OF CONVALESCENCE}

\footnotetext{
$\mathrm{T}$ HE Transactions of two conferences on "Metabolic Aspects of Convalescence" referred to below* make very stimulating reading. Although they are often so specialized that possibly only those who have themselves worked in the particular fields will fully appreciate the significance of some of the questions and answers, yet the general impression left after reading them is that one has made the 'Grand Tour' and become personally acquainted with very interesting people and ideas.

With the exception of the symposium on bone metabolism (Trans. Fourteenth Meeting), the reports are more in the nature of short progress notes rather than balanced statements of experiment and interpretation. As one contributor remarks, "The data presented are of a preliminary nature and are offered in the hope that they may stimulate discussion".

- Conference on Metabolic Aspects of Convalescence. Trans. Thirteenth Meeting, Nawshon Island, Woods Hole, Mass., June 11, 1946. Pp. il +232. 2 dollars. Trans. Fourteenth Meeting, New York, Nov. 2-13, 1946. Pp. ii +190.2 .25 dollars. (Josiah Macy, Jr., Foundation, 65 Park Avenue, New York, 1947.)
}

Convalescence is concermed with the repair of injured tissues and the restoration of normal functioning so that, in effect, the study of its metabolic aspects is very similar to the general study of growth and development. The vast mass of interrelated factors - which scientific workers are only at the beginning of unravelling -is well illustrated by the wide range of subjects covered at these conferences. The reader finds himself switched from "A Comparison of the Effect of Testosterone Propionate on the Enzyme Content of the Kidney and Liver of Castrated and Normal Rats" to "Metabolic Studies before and after Operation of Chronically Ill Patients fed entirely by Vein", or from "Partition Chromatography on Paper" to "Peritoneal Lavage in Uremia". There were sixty-five reports at the thirteenth meeting and thirty-five at the fourteenth. Between them they seem to cover the ground remarkably thoroughly, and anyone whose work is concerned with any aspect of growth or development is likely to find some point of interest which may well give a new turn to his line of thought. The symposium on bone metabolism (a subject to which a large part of earlier meetings in the series has been devoted) forms a contrast to the rest of the papers. The reports presented are longer and more detailed; there is a clear exposition of contrasting hypotheses and a series of very clear photographs.

These reports pose questions rather than provide answers, but they give the impression of being full of helpful clues and well worth studying.

\section{W. Grant}

\section{FORTHCOMING EVENTS}

(Meeting marked with an asterisk * is open to the public)

Monday, April 5 FARMER' CLUB (at the Royal Empire Society, Craven Street.
Strand, London, W.C.2), at 2.30 p.m.--Dr. T. Dalling and Dr. A. W. Strand, London, W.C.2), at 2.30 p.m.
Stableforth: "Bovine Mastitis".

PHYSICAL SOCIETY, LOW-TEMPERATURE GROUP (joint meeting with the INSTITUTE OF REFRIGERATION, at the Chemical Society, Burlington House, Piccadilly, London, W.1), at 5.30 p.m.-Prof. G. Eichelberg : "Heat-Pump Problems and Industrial Realizations".

SOCTETY OF ENGINELRS (at the Geological Society of London, Burlington House, Piceadilly, London, W.1), at 5.30 p.m.-Mr. C. G. Vokes: "Filtration".

ROYAI GEOGRAPHICAI SOCIETY (at Kensington Gore, London S.W.7), at 8.15 p.m.--Mr. John Lawrence: "The Russian Land and History".

\section{Monday, April 5-Tuesday, April 6}

SocrETY OF CHEMrCaL INDUSTRY (in the Mathematics Lecture Theatre, Royal College of Science, Huxley Building, Exhibition Road, London, S.W.7).-Symposium on "Detergents, Wetting and Emulsifying Agents".

Monday, April 5

At 2.15 p.m.- “Synthetic Detergents".

Tuesday, April 6

At 2.15 p.m.- "Wetting Agents and Auxiliary Products".

\section{Tuesday, April 6}

Royal Statistical Society, Regearch Section (at the London School of Hygiene and Tropical Medicine, Keppel Street, London, W.C.1), at 5.15 p.m.-Mr. C. R. Rao: "The Utilization of Multiple Measurements in Problems of Biological Classification".

SOCIRTY OF CHBMICAL INDUSTRY, FOOD GROUP (joint meeting with the GIASGOW SEOTION and the GLASGOW AND DISTRICT SEOTION of the ROYAL INSTITUTE OF CHEMTSTRY, in the Gas Showrooms, Sauchiehall Street, Glasgow), at 2.30 p.m.-Dr. E. C. Bate-Smith : "Refrigeration in Germany"; Mr. H. J. Bunker : "War-time Production of Food Yeast in Germany" ; at 7 p.m.-Mr. J. F. Hearne : "German Albume

Royal ANThropological INstitute (at 21 Bedford Square, Iondon, W.C.1), at 5 p.m.-Mr. Leon Underwood : "African Art and it Place in Art Tradition". 